\title{
MANAGEMENT ACCOUNTING DYNAMICS IN BANGLADESH: AREAS AND FACTORS BEHIND THE CHANGES
}

\author{
Mohammad Rokibul Kabir \\ School of Business Administration, \\ East Delta University, Bangladesh \\ E-mail: rokibul.k@eastdelta.edu.bd
}

\begin{abstract}
Rapid growth in technologies and competitive business environments have brought significant changes in management accounting practices in the manufacturing industries. To cope with these changes a good number of management accounting tools have been developed in helping managerial decisions both at operating and strategic levels. Researchers have identified that the implementation of such tools in developed countries brought success in decision making though research in this particular area in less developed countries, especially in Bangladesh, is not significant yet. Thus, this research aimed to explain the changes that have taken place and the factors behind the changes in management accounting practices (MAP) in manufacturing industries. The listed manufacturing companies in Bangladesh consist of the population and sample of the study. Factor reduction techniques were used to analyze the influencing variables behind the changes in MAP. The paper reveals that the changes that have taken place from 2001 to 2010 period in MAP are mainly in the operational areas while after 2011 the changes in MAP have mostly taken place in the area of strategic decision making. The factors behind the changes are categorized under the heads of Changes in Business and Organization Strategy and Changes in Manufacturing and Information Technology by applying factor analysis.
\end{abstract}

Keywords: Bangladesh, business strategy, changes in decision making, information technology, management accounting, manufacturing

$\underline{\text { ARTICLE INFO }}$

Article History:

Received: 22 November 2018

Accepted: 18 April 2019

Published: 31 August 2019 


\section{INTRODUCTION}

Management accounting has undergone significant changes over the last few decades regarding its scope in making decisions both at the operational and strategic level (Jacobs, 1995). More specifically, its role has increasingly expanded and diversified over the last three decades (Ahmad \& Zabri, 2015). In today's world, it has become crucial for manufacturers to gather accurate cost and other operational information to make managerial decision related to production due to increasing global competition and complexity in the manufacturing environment. Worldwide it is argued that in making more effective production decision leading to increasing profitability, manufacturers must adopt proper management accounting tools (Khajavi \& Nazemi, 2010; Uyar, 2010).

The business environment has hanged rapidly in the recent years as a consequence of the financial crisis which influenced the need for intensified information flow within the organization along with outside information (Van der Stede, 2011). To cope with such rapid changes management accounting facilitates necessary information flow for reshaping organizations (Hopwood, 2009). Thus, a change in the practices of management accounting is forced by such change in business and technological environment (Pavlatos \& Kostakis, 2015). A good number of scholars have argued that despite the bare necessity of changes in management accounting for organizations, the changes that have occurred are much slower than required for providing necessary internal information for decision making (Sorensen, 2009). Thus, the study aims at exploring managerial perception on the area of changes in management accounting practices and the factors driving such changes in the manufacturing concerns of Bangladesh.

\section{THEORETICAL FRAMEWORK AND LITERATURE REVIEW}

\section{Theoretical Background of Management Accounting Changes}

According to Lev and Zambon (2003) a four-stage evolution model explains the development of management accounting as provided by International Federation of Accountants (IFAC) in 1998. 
The first stage of management accounting (MA) development took place up to 1950. Cost determination, financial control and internal matters like production capacity was concentrated in that period were the main concentration in this stage. Application of budgeting and cost accounting were the dominating activities in the first stage of MA development though it was claimed that the use of cost accounting information was not correctly exploited in that period (Jones, 1998). The decade starting from 1950 to 1960 is considered to be the second stage of MA development. Information dissemination for planning and controlling was the main focus in this stage. Application of technology for decision analysis and responsibility accounting were evolved in this stage as well. Internal control and manufacturing development were given priority over strategic and environmental considerations. According to Langfield-Smith (1997), control system in this stage was reactive. Waste reduction and resources management were the prime issues after the shift from the second stage to the third stage of MA development. Improved manufacturing technology, robotics and computer aided production systems were initiated for waste management (Ashton, Hopper \& Scapens, 1995). The emergence of World Wide Web enabled e-commerce and brought revolutionary changes in management accounting practices in this stage. The fourth stage of MA evolution was characterized by a shift to value creation by ensuring optimum utilization of resources. Organizational innovation and increasing stakeholders' value were the main focus of the fourth stage of MA development which is mainly fueled by the rapid development of technology (Abdel-Kader \& Luther, 2006).

The four different stages as described above are not replacement of each other; rather each new stage comprehended the concepts of early stage(s) and included new issues in accordance with the demand of time. The important differences among stage two, stage three and stage four are changes in concentration from utilizing information technology (stage two) to resource management and waste reduction then finally to value creation (Stage four). Still the contemporary MA stage of value creation is directly linked with information technology. Finally, the four stage of MA evolution can be termed as the fourth level of sophistication of management accounting practices where the first stage represents the least sophistication period of MA while the fourth stage is the most sophisticated level of MA. 


\section{Contingencies Driving Changes in Management Accounting Practices}

The changes in the role of accounting that took place in the last couple of decades are mostly influenced by firm specific contingencies (Sorensen, 2009). Strategic priority is found to be important characteristic driving changes in management accounting practices in earlier studies. The study of Baines and Langfield-Smith (2003) found a positive relationship between strategy and changes in management accounting practices. Similarly the finding of Verveeten (2010) revealed organizational strategy as a driving force of changes in management accounting practices.

Changes in manufacturing technology and competitive environment also have important association with changes in management accounting practices. The study of Tuan Mat (2010) supports the argument as stated above.

Rapid technological changes and changes in business environments throughout the world have important role in bringing changes in management accounting style. Sunarni (2013) in his study argued that, in any type of corporation, either manufacturing or non-manufacturing, big, medium or small and either profit oriented or non-profit, it is necessary to adopt changes in management accounting practices to ensure sustainability in the global market.

In the light of above discussion the conceptual framework for factors influencing changes in management accounting practices is shown in the following diagram. 


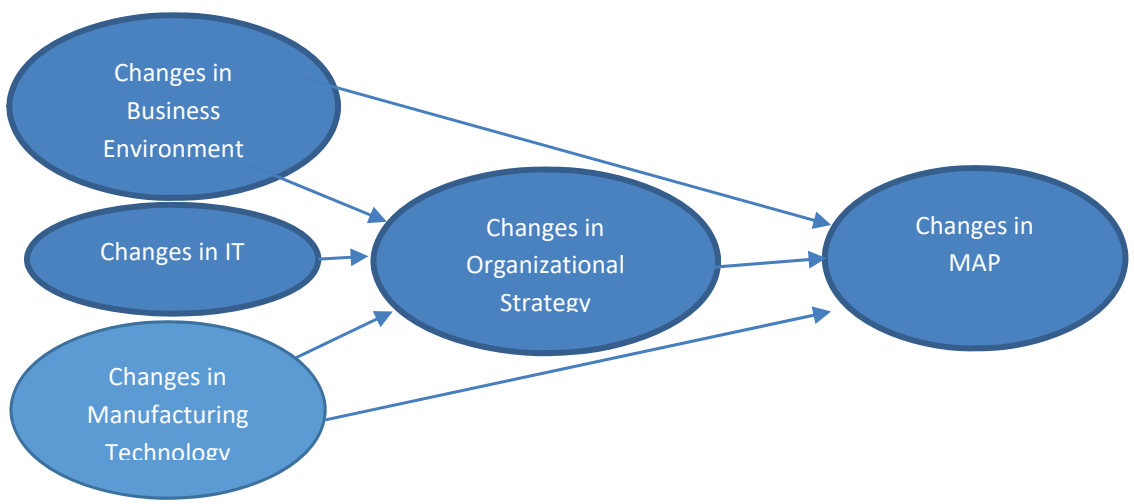

Figure 1: Driving Forces of Changes in Management Accounting Practices Source: Developed by the author through extensive literature survey

\section{Literatures on Factors Driving Changes in Management Accounting Practices}

There are a number of factors which influence the changes in management accounting practices within the organizations (Alleyne \& Weekes-Marshall, 2011). It is a common belief that there is a continuous cycle of resources, which moves from the external environment changes, influencing the selection of the appropriate management accounting practices within any organization and such contingent derived changes in MAP (Otley \& Berry, 1980). Some researchers have commented that such changes may originate due to different settings of both economic and cultural environments. However, Libby and Waterhouse (1996) were convinced that there were changes in management accounting practices in recent years. Burns and Vaivio (2001) further argued that there is evidence that management accounting practices have changed over the last decade in developed countries like the UK.

Subasinghe and Fonseka (2009) remarked that in the next ten-year management accountants will have to modify the way they perceive in their role to support and construct critic to the manager and join the roles of the decision maker. In that study, it has also been revealed that top management awareness, subordinate to financial accounting, mode of planning and control, supportive organizational culture and market volatility significantly influence the changes in management accounting practice. 
Factors like competition for new product development, marketing/ distribution channels competition, no. of competitors in the market segments, flexible manufacturing systems, computer-aided design, computer-aided engineering, computer-aided process planning, computer integrated manufacturing, numerical control, development of it, online marketing strategy, need for faster communication through the internet, providing on-time delivery, making dependable delivery promise, challenges for providing high quality products and need for providing effective after sales service and support have been identified as important variables explaining the changes in management accounting practices (e.g. Lin \& Yu, 2002; Szychta, 2002; Abdel-Maksoud, 2004; Al-Omiri \& Drury, 2007; Tuan Mat, Smith \& Djajadikerta, 2010; Sunarni, 2013; Ahmad \& Zabri, 2015).

\section{METHODOLOGY OF THE STUDY}

\section{The Population of the Study}

The study was conducted on the listed manufacturing companies in Bangladesh. Thus, in selecting the population, two criteria were considered. The companies must be engaged in the manufacturing process and should be listed in the stock exchange before 2011. Thus, the listed companies were selected from Nine (09) different industries engaged in manufacturing operations. Such manufacturing companies have been identified from the published documents and official websites of the Dhaka Stock Exchange and Chittagong Stock Exchange. The reasons for choosing companies listed before 2011 are the necessity and availability of financial data along with the maturity level of the companies as a listed company. Thus, the population of the study consisted of One Hundred and One (101) companies which fulfil the above-mentioned criteria.

\section{Sampling Design}

To select the sample companies, the randomized block sampling technique was used. First, the listed companies in the population were divided into blocks with homogenous characteristics. Here, homogeneity is determined based on the industry type. Since the output, production technique, technological involvement, sophistication in the production process, investment size and labour orientation are different from one 
industry to other; each industry consisted of a block with homogenous features. Thus, there were nine blocks for nine different industries from which samples were determined on a random basis.

\section{Sample Size Determination}

Randomized block designs were constructed to reduce noise or variance in the data. It required that the researcher divide the sample into relatively homogeneous subgroups or blocks. Then, the random sampling technique was used within each block or homogeneous subgroup. By using the sample size table for a finite population as suggested by Dupont and Plummer (1990), the appropriate number of companies for the study was selected. The $95 \%$ confidence level with a $5 \%$ margin of error was chosen to determine the sample size.

The blocks for the study along with the number of companies in each block, required a number of samples to be taken and the sample size are highlighted in the following table:

Table 1: Population Size, Minimum Sample Size Requirement and Actual Sample Size

\begin{tabular}{|c|c|c|c|c|c|c|c|c|c|c|}
\hline Name of the Industry (Block) & 苍 & $\frac{0}{\frac{0}{\pi}}$ & 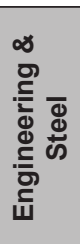 & 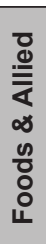 & 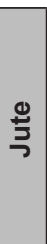 & 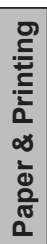 & 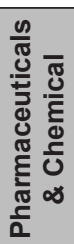 & 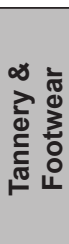 & 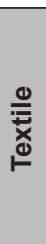 & 흄 \\
\hline Number of companies in the block & 5 & 5 & 19 & 15 & 3 & 2 & 22 & 5 & 25 & 101 \\
\hline $\begin{array}{l}\text { Required number samples as per } \\
\text { the sample size table }\end{array}$ & 5 & 5 & 17 & 13 & 3 & 2 & 20 & 5 & 22 & $\begin{array}{c}88 \\
\text { (Min } \\
\text { imum) }\end{array}$ \\
\hline Number of sample from each block & 5 & 5 & 17 & 13 & 3 & 2 & 20 & 5 & 22 & 92 \\
\hline $\begin{array}{l}\text { Sources: Websites of Dhaka Stock } \\
\text { Exchange and Chittagong Stock } \\
\text { Exchange and author's calculation } \\
\text { for sample size determination }\end{array}$ & & & & & & & & & & \\
\hline
\end{tabular}




\section{Study Period}

The data period of the study consisted of Fifteen (15) years from 2001 to 2015. The survey through a questionnaire (including interview and pilot survey) was initiated on $2^{\text {nd }}$ February, 2014 and carried on till $4^{\text {th }}$ November 2015 to complete the whole survey for observing the changes in a 15-year period under two different segments of 2001 to 2010 and 2011 to 2015. The reasons for such a long data collection period include, among others, the repeated amendment of the questionnaire after each interview and pilot survey, unavailability of all the respondents within a short time and delay in returning the filled questionnaire which was asked through mail.

\section{Selection of Variables}

Table 2: Selection of Variables Influencing Changes in Map with Sources

\begin{tabular}{lll}
\multicolumn{2}{c}{ in Management Accounting Practices } & Source Research \\
\hline Competitive & - Price competition & Sunarni (2013); \\
Business & - Competition for new product development & Lin and Yu, (2002); \\
Environment & - Marketing/distribution channels competition & Mat (2010) \\
& - No. of competitors in your market segments & \\
\hline Manufacturing & - Flexible manufacturing systems (FMS) & Zafar, Shaukat and \\
Technology & - Computer-aided manufacturing (CAM) & Mat (2010); \\
& - Computer-aided design (CAD) & Sunarni (2013); \\
& - Computer-aided engineering (CAE) & Al-Omiri and Drury, \\
& - Computer-aided process planning (CAPP) & (2007); \\
& - Computer integrated manufacturing(CIM) & Szychta (2002) \\
& - Numerical control (NC) & \\
\hline Information & - Development of Information Technology & Sunarni (2013); \\
Technology & - Online Marketing Strategy & Abdel-Maksoud, \\
& - Need for Faster Communication through & (2004); \\
& The internet & Zafar, Shaukat and \\
& & Mat (2010); \\
\hline Organizational & - Provide on time delivery & Zafar, Shaukat and \\
strategy & - Make dependable delivery promise & Mat (2010); \\
& - Provide high quality products & Sunarni (2013); \\
& - Provide effective after sales service and & Ahmad and Zabri \\
& support & (2015) \\
& & Szychta (2002) \\
\hline
\end{tabular}




\section{Preparation of the Questionnaire}

The study is mainly based on primary data collected through a structured questionnaire. Both direct and postal questionnaires were used to collect empirical data. This facilitated access to tap the management accountants and/or production managers (PMs) of all the sample companies. In addition, a limited number of face-to-face interviews were carried out. The interviews were used to pilot and amend the questionnaire before sending it out and, later, to check the reliability of the survey results and seeks further explanation of some of the responses. Four pilot interviews (two management accountants and two PMs) were undertaken before the questionnaires were sent out. After each interview, the questionnaires were modified according to comments received. The questionnaires were also reviewed by four academics.

\section{Factor Analysis for the Driving Forces of Management Accounting Practices}

Changes in management accounting practices are evident from several recent accounting literature (Sunarni, 2013). For example, Yazdifar and Tsamenyi (2005) argued in favour of changes in MAP through the application of modern management accounting tools and techniques. Similarly, Waweru, Hoque and Uliana (2005) stated that the environment in which management accounting is practised certainly appears to have changed with advances in information technology, highly competitive environments and economic recession as found in contemporary literature on management accounting.

Burns and Scapens (2000) argued the competitive economic situation, especially global competition, as the most frequently cited driver of change in management accounting. When organizations face considerable environmental changes, the traditional management accounting role, comprising formal controls and reporting procedures, is simply not adequate to meet these new demands. Hence managerial accounting systems need to be updated and modified accordingly to accommodate the new, different informational needs (Malmi, Seppala \& Rantanen, 2001). 
Sunarni (2013); Lin and Yu, (2002) and Tuan Mat, Smith, and Djajadikerta (2010) identified competitive business environment (under which there are four factors) while Sunarni (2013); Al-Omiri and Drury (2007) and Szychta (2002) described about advanced manufacturing technology including seven items as the driving forces of management accounting changes. Again, Sunarni (2013); Abdel-Maksoud, (2004) and Tuan Mat, Smith, and Djajadikerta (2010) explored information technology as the important contingent, which includes three items, to influence changes in MAP. Sunarni (2013); Ahmad and Zabri (2015) and Szychta (2002) explained four factors under the contingent called organizational strategy. To ensure the powerful factors have a real impact on management accounting changes, the above mentioned variables were summarized by the factor reduction technique through the statistical software called SPSS 20.

\section{RESULTS AND DISCUSSIONS}

\section{Factors Influencing Changes in Management Accounting}

The important factors bringing changes in management account practices as revealed from earlier studies through an extensive literature survey are categories under Business Environment, Manufacturing Technology, Information Technology and Business Strategy. The following table shows such influencing factors driving changes in management accounting practices in the manufacturing companies in Bangladesh. 
Table 3: Factors Influencing Changes in Management Accounting

\begin{tabular}{|c|c|c|c|c|c|c|}
\hline \multirow{2}{*}{\multicolumn{2}{|c|}{$\begin{array}{c}\text { Factors Driving Changes in Management } \\
\text { Accounting Practices } \\
\text { Very Influencing (5) }\end{array}$}} & \multicolumn{5}{|c|}{ Level of Influences for Changes } \\
\hline & & 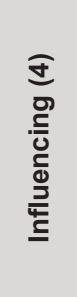 & 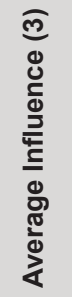 & 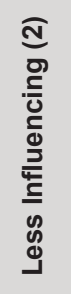 & 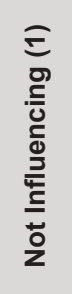 & 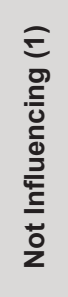 \\
\hline \multirow[t]{3}{*}{$\begin{array}{l}\text { Business } \\
\text { Environment }\end{array}$} & $\begin{array}{l}\text { Competition for new product } \\
\text { development }\end{array}$ & $78 \%$ & $22 \%$ & 0 & 0 & 0 \\
\hline & $\begin{array}{l}\text { Marketing/distribution channels } \\
\text { competition }\end{array}$ & 0 & $68 \%$ & $32 \%$ & 0 & 0 \\
\hline & $\begin{array}{l}\text { No. of competitors in your market } \\
\text { segments }\end{array}$ & $82 \%$ & $18 \%$ & 0 & 0 & 0 \\
\hline \multirow[t]{7}{*}{$\begin{array}{l}\text { Manufacturing } \\
\text { Technology }\end{array}$} & $\begin{array}{l}\text { Flexible manufacturing systems } \\
\text { (FMS) }\end{array}$ & 0 & 0 & $82 \%$ & $15 \%$ & $3 \%$ \\
\hline & $\begin{array}{l}\text { Computer-aided manufacturing } \\
\text { (CAM) }\end{array}$ & 0 & $79 \%$ & $21 \%$ & 0 & 0 \\
\hline & Computer-aided design (CAD) & $89 \%$ & $11 \%$ & 0 & 0 & 0 \\
\hline & Computer-aided engineering (CAE) & $45 \%$ & $28 \%$ & $23 \%$ & $4 \%$ & 0 \\
\hline & $\begin{array}{l}\text { Computer-aided process planning } \\
\text { (CAPP) }\end{array}$ & $28 \%$ & $52 \%$ & $14 \%$ & $6 \%$ & 0 \\
\hline & $\begin{array}{l}\text { Computer integrated } \\
\text { manufacturing(CIM) }\end{array}$ & $22 \%$ & $43 \%$ & $30 \%$ & $5 \%$ & 0 \\
\hline & Numerical control (NC) & $9 \%$ & $21 \%$ & $50 \%$ & $20 \%$ & 0 \\
\hline \multirow{3}{*}{$\begin{array}{l}\text { Information } \\
\text { Technology }\end{array}$} & Development of IT & $72 \%$ & $24 \%$ & $4 \%$ & 0 & 0 \\
\hline & Online Marketing Strategy & $32 \%$ & $43 \%$ & $18 \%$ & $7 \%$ & 0 \\
\hline & $\begin{array}{l}\text { Need for Faster Communication } \\
\text { through The internet }\end{array}$ & 0 & 0 & $58 \%$ & $42 \%$ & 0 \\
\hline \multirow{4}{*}{$\begin{array}{l}\text { Business } \\
\text { Strategy }\end{array}$} & Provide on time delivery & $97 \%$ & $3 \%$ & 0 & 0 & 0 \\
\hline & Make dependable delivery promise & $72 \%$ & $26 \%$ & $2 \%$ & 0 & 0 \\
\hline & Provide high quality products & $92 \%$ & $8 \%$ & 0 & 0 & 0 \\
\hline & $\begin{array}{l}\text { Provide effective after sales service } \\
\text { and support }\end{array}$ & $21 \%$ & $39 \%$ & $40 \%$ & 0 & 0 \\
\hline
\end{tabular}

Source: Author's findings 
Under the heading Business Environment, the number of competitors in the market segment seems to be the most influencing driver of change in the management accounting practices followed by competition for new product development. In the segment of manufacturing technology, computer-aided design (CAD) is the most influencing factor followed by, computer-aided design (CAE) and computer-aided process planning (CAPP). The least influencing driver of change in the management accounting practices is flexible manufacturing systems (FMS). Development of information technology (IT) and online marketing strategies are the main influencing variables under the heading Information Technology. Finally, the most influencing factors under the head Business Strategy includes the demand of customers for providing on-time delivery followed by the assurance for high-quality products. Making a dependable delivery promise is also an important driver. If we consider all the factors together the most three (3) important and influencing variables would be demand for providing on time delivery, ensuring high quality products and application of computer-aided manufacturing.

\section{Factor Analysis for Identifying Variables with High Impact for Driving Changes in Management Accounting Practices}

To explore the factors driving changes in management accounting practices, respondent were asked to answer 17 questions on a 5-point likert scale ranging from 1 (not influencing) to 5 (very influencing). Factor analysis has been employed using SPSS 20. Reliability analysis was conducted and the Cronbach alpha was determined as .92 (see table 4) which indicates reliability of the scale. Further, factor analysis was applied to 17 variables. Table 4 shows the Kaiser-Meyer-Olkin (KMO) measure of sampling adequacy and the Bartlett's test of sphericity.

Table 4: KMO and Bartlett's Test

\begin{tabular}{|c|c|c|}
\hline \multicolumn{2}{|c|}{$\begin{array}{c}\text { Cronbach alpha } \\
\text { Kaiser-Meyer-Olkin Measure of Sampling Adequacy }\end{array}$} & $\begin{array}{l}.92 \\
912\end{array}$ \\
\hline \multirow{3}{*}{ Bartlett's Test of Sphericity } & Approx. Chi-Square & 2769.570 \\
\hline & Df & 136 \\
\hline & Sig. & .000 \\
\hline
\end{tabular}

Source: Author's findings 
From Table 4 it is observed that the value of $\mathrm{KMO}$ is determined as 0.912 and the Bartlett's test of sphericity as 2769.570 (significant at 1 percent, $p<0.000$ ) that justify the usage of factor analysis.

Table 5: Total Variance Explained

\begin{tabular}{ccccccc}
\hline & \multicolumn{3}{c}{ Initial Eigenvalues } & \multicolumn{2}{c}{$\begin{array}{c}\text { Extraction Sums of Squared } \\
\text { Loadings }\end{array}$} \\
\cline { 2 - 7 } Component & Total & $\begin{array}{c}\text { \% of } \\
\text { Variance }\end{array}$ & $\begin{array}{c}\text { Cumulative } \\
\%\end{array}$ & Total & $\begin{array}{c}\% \text { of } \\
\text { Variance }\end{array}$ & $\begin{array}{c}\text { Cumulative } \\
\%\end{array}$ \\
\hline 1 & 12.162 & 71.542 & 71.542 & 12.162 & 71.542 & 71.542 \\
\hline 2 & 1.775 & 9.438 & 81.980 & 1.775 & 9.438 & 81.980 \\
\hline 3 & .882 & 5.191 & 87.171 & & & \\
\hline 4 & .719 & 4.230 & 91.401 & & \\
\hline 5 & .526 & 3.094 & 94.495 & & \\
\hline 6 & .268 & 1.578 & 96.073 & & \\
\hline 7 & .162 & .952 & 97.025 & & & \\
\hline 8 & .099 & .584 & 97.609 & & & \\
\hline 9 & .081 & .475 & 98.084 & & & \\
\hline 10 & .077 & .452 & 98.536 & & & \\
\hline 11 & .063 & .368 & 98.905 & & & \\
\hline 12 & .053 & .311 & 99.216 & & & \\
\hline 13 & .043 & .254 & 99.470 & & & \\
\hline 14 & .032 & .186 & 99.656 & & \\
\hline 15 & .025 & .148 & 99.804 & & \\
\hline 16 & .020 & .119 & 99.923 & & \\
\hline 17 & .013 & .077 & 100.000 & & \\
\hline
\end{tabular}

Extraction Method: Principal Component Analysis.

Source: Author's findings

Factor analysis was performed using the principal component extraction method with varimax rotation, on the basis of Eigen value not less than 1 for any factor. Table 5 shows the Eigen values, percentage of variance explained by the factors extracted and cumulative percentage of variance explained. It is observed that on the basis of Eigen value two components were extracted. None of the other components had the Eigen value of 1 or more. Thus, two components with a cumulative Variance percentage of $81.980 \%$ construct the principle component matrix explaining the total variance. 
Table 6: Rotation Matrix

\begin{tabular}{lcc} 
& Component 1 & Component 2 \\
\hline Make dependable delivery promise & .911 & .012 \\
\hline Provide on time delivery & .899 & .346 \\
\hline Competition for new product development & .894 & .130 \\
\hline No. of competitors in your market segments & .872 & .247 \\
\hline Marketing/distribution channels competition & .863 & -.220 \\
\hline $\begin{array}{l}\text { Need for Faster Communication through The } \\
\text { internet }\end{array}$ & .775 & -.438 \\
\hline Provide effective after sales service and & .772 & -.548 \\
support & .724 & .510 \\
\hline Provide high quality products & .508 & .486 \\
\hline Flexible manufacturing systems & -.146 & .932 \\
\hline Online Marketing Strategy & .076 & .928 \\
\hline Development of IT & -.061 & .924 \\
\hline Computer-aided process planning & -.196 & .924 \\
\hline Computer-aided engineering & .173 & .892 \\
\hline Computer-aided manufacturing & -.328 & .879 \\
\hline Computer integrated manufacturing & -.302 & .822 \\
\hline Numerical control & .492 & .747 \\
\hline Computer-aided design &
\end{tabular}

Table 6 shows the rotation matrix where the variables under component one and component two are specified. It is to be noted that factor loading of more than 0.5 was taken as the lowest boundary for the study to be considered a variable under any component. Component 1 consisted of nine variables while there are eight variables in component 2 . Table 7 segregates the variables under two components on the basis of factor loading. 
Table 7: Influencing Factors Behind Management Accounting Changes

\begin{tabular}{|c|c|c|c|}
\hline $\begin{array}{l}\text { Component-1 (Changes in } \\
\text { Business and Organization } \\
\text { Strategy) }\end{array}$ & Factor & $\begin{array}{l}\text { Component-2 (Changes in } \\
\text { Manufacturing and Information } \\
\text { Technology) }\end{array}$ & Factor \\
\hline Make dependable delivery promise & .911 & Online marketing strategy & .932 \\
\hline Provide on time delivery & .899 & Development of IT & .928 \\
\hline $\begin{array}{l}\text { Competition for new product } \\
\text { development }\end{array}$ & .894 & $\begin{array}{l}\text { Computer-aided process } \\
\text { planning }\end{array}$ & .924 \\
\hline $\begin{array}{l}\text { No. of competitors in your market } \\
\text { segments }\end{array}$ & .872 & Computer-aided engineering & .924 \\
\hline $\begin{array}{l}\text { Marketing/distribution channels } \\
\text { competition }\end{array}$ & .863 & Computer-aided manufacturing & .892 \\
\hline $\begin{array}{l}\text { Need for faster communication via } \\
\text { internet }\end{array}$ & .775 & $\begin{array}{l}\text { Computer integrated } \\
\text { manufacturing }\end{array}$ & .879 \\
\hline $\begin{array}{l}\text { Provide effective after sales service } \\
\text { and support }\end{array}$ & .772 & Numerical control & .822 \\
\hline Provide high quality products & .724 & Computer-aided design & .747 \\
\hline Flexible manufacturing systems & .508 & & \\
\hline
\end{tabular}

Nine factors called dependable delivery promise, on time delivery, competition for new product development, no. of competitors in your market segments, marketing/distribution channels competition, need for faster communication through the internet, effective after sales service, providing high-quality products and support and flexible manufacturing systems constitute component 1 . On the basis of similarity in the characteristics, the factors under component 1 are thought to be named as 'Changes in Business and Organization Strategy'. On the other hand, there are eight factors under component 2 called online marketing strategy, development of IT, computer-aided process planning, computer-aided engineering, computeraided manufacturing, computer integrated manufacturing, numerical control and computer-aided design. Since the factors under component 2 are mainly based on technology like modern manufacturing systems and IT, it is named as Changes in Manufacturing and Information Technology.

Hence, the proposed model for driving changes in management accounting can be redesigned and finalized as follows: 


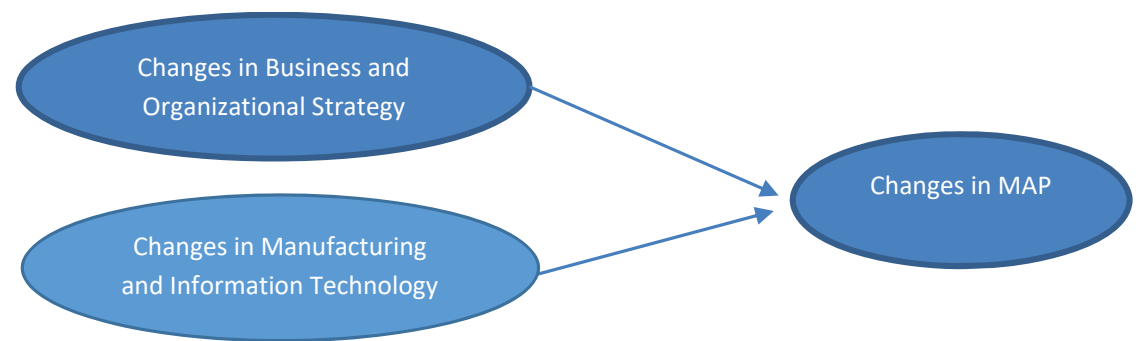

Figure 2: Driving Forces of Changes in Management Accounting Practices Source: Developed by the author on the basis of the findings

Area of Changes in Management Accounting Practices during 20012010

\section{Table 8: Area of Changes in Management Accounting Practices During 2001-2010}

\begin{tabular}{|c|c|c|c|c|c|}
\hline \multicolumn{2}{|c|}{ Area of Changes during 2001-2010 } & \multicolumn{4}{|c|}{ Percentage of Changes in Companies } \\
\hline Area or Cnanges & auring $2001-2010$ & $\begin{array}{c}\text { Percent } \\
\text { Increased }\end{array}$ & $\begin{array}{c}\text { Percent } \\
\text { Decreased }\end{array}$ & $\begin{array}{c}\text { Percent } \\
\text { Replaced }\end{array}$ & $\begin{array}{c}\text { No } \\
\text { Change }\end{array}$ \\
\hline \multirow{6}{*}{ Operational Areas } & $\begin{array}{l}\text { Changes in Costing } \\
\text { Method }\end{array}$ & $58 \%$ & $0 \%$ & $41 \%$ & $1 \%$ \\
\hline & $\begin{array}{l}\text { Changes in Pricing } \\
\text { Method }\end{array}$ & $66 \%$ & $2 \%$ & $26 \%$ & $6 \%$ \\
\hline & $\begin{array}{l}\text { Changes in Budgeting } \\
\text { System }\end{array}$ & $35 \%$ & $0 \%$ & $38 \%$ & $27 \%$ \\
\hline & $\begin{array}{l}\text { Changes in Profitability } \\
\text { Analysis System }\end{array}$ & $45 \%$ & $3 \%$ & $41 \%$ & $11 \%$ \\
\hline & $\begin{array}{l}\text { Changes in Investment } \\
\text { decision-making } \\
\text { Pattern }\end{array}$ & $76 \%$ & $1 \%$ & $18 \%$ & $5 \%$ \\
\hline & Mean & $56 \%$ & $1.2 \%$ & $32.8 \%$ & $10 \%$ \\
\hline \multirow[t]{3}{*}{$\begin{array}{l}\text { Performance } \\
\text { Measurement and } \\
\text { Reward System Areas }\end{array}$} & $\begin{array}{l}\text { Changes in } \\
\text { Performances } \\
\text { Measurement System }\end{array}$ & $45 \%$ & $8 \%$ & $35 \%$ & $12 \%$ \\
\hline & $\begin{array}{l}\text { Changes in Reward } \\
\text { System }\end{array}$ & $35 \%$ & $17 \%$ & $14 \%$ & $34 \%$ \\
\hline & Mean & $40 \%$ & $12.5 \%$ & $24.5 \%$ & $23 \%$ \\
\hline \multirow{4}{*}{ Strategic Areas } & $\begin{array}{l}\text { Changes in Strategic } \\
\text { Decision Making } \\
\text { System }\end{array}$ & $31 \%$ & $5 \%$ & $23 \%$ & $41 \%$ \\
\hline & $\begin{array}{l}\text { Changes in Long- } \\
\text { range Business } \\
\text { Planning } \\
\end{array}$ & $27 \%$ & $2 \%$ & $32 \%$ & $39 \%$ \\
\hline & $\begin{array}{l}\text { Changes in New } \\
\text { Product Development } \\
\text { Decision Method }\end{array}$ & $39 \%$ & $1 \%$ & $11 \%$ & $49 \%$ \\
\hline & Mean & $32.33 \%$ & $2.67 \%$ & $22 \%$ & $43 \%$ \\
\hline
\end{tabular}

Source: Author's findings 
Table 8 shows the changes that have taken place in Management Accounting Practices during 2001-2009. It is revealed that 58\% of the companies in the sample introduced new tools for costing while $41 \%$ of the companies replaced their existing costing system with a new method whereas $1 \%$ did not make any change in costing method.

$66 \%$ of the companies in the sample introduced new tools for pricing and $26 \%$ replaced their existing pricing system with a new method whereas $6 \%$ did not make any change in their costing method. Only $2 \%$ of the sample companies decreased the existing pricing method to simplify the system.

$38 \%$ companies replaced their traditional budgeting with zero based and flexible budgeting methods. $35 \%$ of the sample firms used alternative budgeting method along with their traditional budget.

$45 \%$ of the companies adopted additional profitability analysis tools to make sure they are doing well while $41 \%$ of the companies replaced their existing system of profitability analysis with a new system.

The highest number of companies changed their investment decisionmaking pattern as it is evident that $76 \%$ of the companies in the sample introduced additional investment decision tools.

Thus, during the decade of 2001 to 2010 most changed operational tools are investment decision-making tools and costing tools.

$45 \%$ of the companies in the sample introduced new tools for performance measurement while $35 \%$ of the companies replaced their existing performance measurement system with a new method whereas $12 \%$ did not make any change in this regard. $35 \%$ of the companies in the sample introduced new tools for ensuring the proper rewarding of employees and $34 \%$ did not make any changes while $14 \%$ replaced their existing system.

In the strategic area least changes have been observed. In the case of $49 \%$ companies, no changes had taken place in the new product development decision method, $41 \%$ companies did not bring any change in the strategic decision making system and 39\% companies did not feel the necessity of bringing any change in long-range business planning. 
Among the three areas of changes in management accounting practices, maximum changes have been seen in the operational area as $90 \%$ changes have been taken place during the period of 2000 to 2009. In the area of performance measurement and reward system $77 \%$ changes had taken place while only $67 \%$ changes were observed in the strategic area.

Area of Changes in Management Accounting Practices during 20112015

Table 9: Area of Changes in Management Accounting Practices During 2011-2015

\begin{tabular}{|c|c|c|c|c|c|}
\hline \multicolumn{2}{|c|}{ Area of Changes during 2011-2015 } & \multicolumn{4}{|c|}{ Percentage of Changes in Companies } \\
\hline 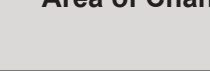 & 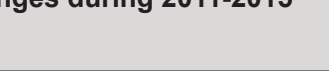 & $\begin{array}{l}\text { Percent } \\
\text { Increased }\end{array}$ & $\begin{array}{c}\text { Percent } \\
\text { Decreased }\end{array}$ & $\begin{array}{l}\text { Percent } \\
\text { Replaced }\end{array}$ & $\begin{array}{c}\text { No } \\
\text { Change }\end{array}$ \\
\hline \multirow{6}{*}{$\begin{array}{l}\text { Operational } \\
\text { Areas }\end{array}$} & $\begin{array}{l}\text { Changes in Costing } \\
\text { Method }\end{array}$ & $21 \%$ & $2 \%$ & $39 \%$ & $38 \%$ \\
\hline & $\begin{array}{l}\text { Changes in Pricing } \\
\text { Method }\end{array}$ & $46 \%$ & $0 \%$ & $24 \%$ & $30 \%$ \\
\hline & $\begin{array}{l}\text { Changes in Budgeting } \\
\text { System }\end{array}$ & $39 \%$ & $2 \%$ & $45 \%$ & $14 \%$ \\
\hline & $\begin{array}{l}\text { Changes in Profitability } \\
\text { Analysis System }\end{array}$ & $35 \%$ & $1 \%$ & $24 \%$ & $40 \%$ \\
\hline & $\begin{array}{l}\text { Changes in Investment } \\
\text { decision-making Pattern }\end{array}$ & $36 \%$ & $4 \%$ & $21 \%$ & $39 \%$ \\
\hline & Mean & $35.4 \%$ & $1.8 \%$ & $30.6 \%$ & $32.2 \%$ \\
\hline \multirow{3}{*}{$\begin{array}{l}\text { Performance } \\
\text { Measurement } \\
\text { and Reward } \\
\text { System Areas }\end{array}$} & $\begin{array}{l}\text { Changes in } \\
\text { Performances } \\
\text { Measurement System }\end{array}$ & $55 \%$ & $3 \%$ & $32 \%$ & $10 \%$ \\
\hline & $\begin{array}{l}\text { Changes in Reward } \\
\text { System }\end{array}$ & $57 \%$ & $1 \%$ & $37 \%$ & $5 \%$ \\
\hline & Mean & $56 \%$ & $2 \%$ & $34.5 \%$ & $7.5 \%$ \\
\hline \multirow{4}{*}{ Strategic Areas } & $\begin{array}{l}\text { Changes in Strategic } \\
\text { Decision Making System }\end{array}$ & $51 \%$ & $0 \%$ & $37 \%$ & $12 \%$ \\
\hline & $\begin{array}{l}\text { Changes in Long-range } \\
\text { Business Planning }\end{array}$ & $55 \%$ & $3 \%$ & $37 \%$ & $1 \%$ \\
\hline & $\begin{array}{l}\text { Changes in New Product } \\
\text { Development Decision } \\
\text { Method }\end{array}$ & $67 \%$ & $5 \%$ & $26 \%$ & $2 \%$ \\
\hline & Mean & 57.66 & $2 \%$ & $33.33 \%$ & $5 \%$ \\
\hline
\end{tabular}

Source: Author's findings

The changes in management accounting practices during 2011-2015 are highlighted in Table 9 . The results of the study indicate that $39 \%$ of the sample companies had replaced their existing costing tools and $21 \%$ of the 
companies introduced new tools for costing while 38\% did not make any change in their costing method.

In the case of pricing tools, about $70 \%$ of the companies either introduced new pricing tools or replaced the exiting tools with new pricing tools. The rest of the $30 \%$ of the companies did not bring any change in their application of pricing tools.

$39 \%$ of the companies introduced new budgeting tools whereas $45 \%$ of the sample companies replaced their budgeting tools with new budgeting techniques. On the other hand, $14 \%$ of the companies did not make any change in the application of budgeting tools.

$59 \%$ of the companies either adopted additional profitability analysis tools or replaced their existing tools for better measurement of profitability whereas $40 \%$ of the companies did not make any change. $39 \%$ of the companies in the sample did not introduce or make any change in their investment decision-making pattern while $36 \%$ introduced a new technique and $21 \%$ replaced their old system with new one for an investment decision. Hence, the changes in profitability analysis tools and investment decision making tools are comparatively lower than the changes in other tools. The reason might be the changes in the use of such tools have been emphasized in the early period of 2001 to 2010.

Thus, during the period 2011 to 2015, most changes in the operational areas of management accounting practice are related to the budgeting system immediately followed by the changes in pricing methods. The least changes took place in the application of investment decision-making techniques. According to the respondents in most of the cases the companies faced challenges by new competitors from both home and abroad and prices of standardized products have been reduced while custom made products were charged differently which influenced the companies to apply new innovative technique of pricing for different segments of the market. Moreover, rapid technological developments forced the companies to adopt a flexible budged and other new budgetary tools during the 2011 to 2015 period. On the other hand, the changes in investment decision making tools have taken place in the last few years of the first phase of the study period. 
$55 \%$ of the companies in the sample introduced new tools for performance measurement while $32 \%$ of the companies replaced their existing performance measurement system with a new method whereas $10 \%$ did not make any change in this regard. During the period 2011 to 2015, the gear shifted from operational changes to changes in strategic decision making and performance measurement. Comparatively modern management accounting tools like the Balanced Scorecard and CIMA Strategy Scorecard were seen to be used by some companies as they started focusing on strategic decision making due to the changes taking place in the business environment and adoption of information technology in every sector of Bangladesh with the slogan of 'Digital Bangladesh 'of the newly elected government in 2014.

About $94 \%$ of the sample companies either introduced new reward system tools or replaced their existing reward system with a new system. Thus, a big change was observed in the area of performance measurement and reward system.

In the 2011 to 2015 period a remarkable change was seen in strategic areas. $96 \%$ of the companies brought changes in long-range business planning during this period of 2010 to 2015 . Similarly, $93 \%$ of the companies changed their new product development decision method while $88 \%$ of the companies changed their strategic decision making system.

Thus, during the period of 2011 to 2015 , maximum changes were seen in the strategic area with around $93 \%$ positive initiatives to bring a new style in this area whereas least changes were observed in the operational area as around $32 \%$ companies did not bring any change in this area. In the area of performance measurement and reward system about $91 \%$ of changes were observed during the period of 2011-2015.

Thus, we can summarize that 2001-2010 was the period of emphasizing on operational issues while 2011-2015 was the period of concentration on strategic issues of management accounting. 


\section{CONCLUSION}

The driving forces of management accounting practices were studied under four headings called Business Environment, Manufacturing Technology, Information Technology and Business Strategy. The most influencing driving force for changes in management accounting practices is the number of competitors in the market segment followed by competition for new product development under the heading Business Environment. In the segment of manufacturing technology, computer-aided design (CAD) is the most influencing factor followed by, computer-aided engineering (CAE) and computer-aided process planning (CAPP). Development of information technology (IT) and online marketing strategies are the main influencing variables under the heading Information Technology. Finally, the most influencing factors under the heading Business Strategy includes the demand of customers for providing on time delivery followed by the assurance for high quality products. The variables having the highest impact on the changes in management accounting would be demand for providing on time delivery, ensuring high quality products and application of computer-aided manufacturing.

The findings of the study support the finding of earlier studies of Lin and Yu (2002); Szychta (2002); Abdel-Maksoud (2004); Al-Omiri and Drury (2007); Mat et al. (2010); Sunarni (2013); Ahmad and Zabri (2015). The factors identified as the influencing variables in management accounting changes are similar to those identified in different developed and developing countries. The results of factor analysis ensure the variables having influence on management accounting changes can be categorized under two components. On the basis of the characteristics of the variables in each component, the first component is named as Changes in Business and Organization Strategy while the second component is named as Changes in Manufacturing and Information Technology.

The changes in management accounting practices were analyzed in two phases. The first phase includes the period from 2001 to 2010 and the second phase includes 2011 to 2015 period. The changes during the said period were analyzed in three areas called operational areas, performance measurement \& reward system areas and strategic areas. 90\% changes have taken place in the operational area during the period of 2000 to 2010 
which is the highest. Bangladesh has achieved a tremendous growth in production, export and GDP during the period of 2001 to 2010, especially between the years of 2006 and 2007. The tremendous growth of GDP from $5.3 \%$ in 2000 to $7.1 \%$ in 2007 (World Bank, 2019) and the amount of export of USD 5493226.43 thousand in 2000 to USD 19230982.56 thousand in 2010 (WITS, 2019) show the acceleration in the economic development of Bangladesh. Such a growth was achieved because of the changes that have taken place in the manufacturing and operational process of the producers. To compete in the international market, manufacturers emphasized much in the operational areas like cost control, pricing method and so on. They started using Activity Based Costing, Quality Costing and Target costing which they were not using much before. Similarly, companies started using Market Sensitive Pricing and Segmental Pricing for different types of consumers for the domestic and export market. Value Chain Analysis and 360 Degree Feedback were also introduced by a few companies to meet the demand for quality products in the international market. In the area of performance measurement and reward system, 77\% changes took place while only $67 \%$ changes have been observed in the strategic area. A remarkable change was seen in strategic areas during 2011 to 2015 period as $96 \%$ of the companies brought changes in long-range business planning during this period. Similarly, $93 \%$ of the companies changed their new product development decision method while $88 \%$ of the companies changed their strategic decision making system. Thus, it can be concluded that operational areas of cost control and budgeting were the main concern in the 2001-2010 period while strategic decision making and performance measurement systems were the major concerns during the 2011-2015 period.

Subasinghe and Fonseka (2009) argued that in the next ten years management accountants will have to modify the way they perceive their role to support and construct critic to manager and join the roles of decision maker. The findings of the study reflects the justification of his argument as the changes that have taken place after 2011 in management accounting practices are mostly in the area of strategic decision making.

The results and the analysis of the study have revealed some additional questions which need to be answered in future studies. Areas need to be explored for enriching management accounting researches may be summarized as follows: 
A comprehensive study may be undertaken including non-listed companies as well because there are a good number of companies having excellent performance which are not listed in the stock exchanges of Bangladesh. Even such non-listed companies include giant companies like Unilever.

To examine the current management accounting practices, this study surveyed the accountants of the public listed companies in Bangladesh. Future studies may consider using the observation technique to provide more in-depth analysis on the current management accounting practices.

The service industries also need to apply management accounting tools for success. In fact, it is equally important to apply managerial decisionmaking tools in the service industry. Hence, a comprehensive analysis of management accounting practices in service industries like banks and hospitals may also be undertaken.

\section{REFERENCES}

Abdel-Kader, M., \& Luther, R. (2006). IFAC's conception of the evolution of management accounting: A research note. Advances in Management Accounting, 15, 229-247.

Abdel-Maksoud, A. B. (2004). Manufacturing in the UK: Contemporary characteristics and performance indicators. Journal of Manufacturing Technology Management, 15(2), 155-171.

Ahmad, K., \& Zabri, S. M. (2015). Factors explaining the use of management accounting practices in Malaysian medium-sized firms. Journal of Small Business and Enterprise Development, 22(4), 762-781.

Alleyne, P., \& Weekes-Marshall, D. (2011). An exploratory study of management accounting practices in manufacturing companies in Barbados. International Journal of Business and Social Science, 2(10), 49-58. 
Al-Omiri, M., \& Drury, C. (2007). A survey of factors influencing the choice of product costing systems in UK organizations. Management Accounting Research, 18(4), 399-424.

Ashton, D., Hopper, T., \& Scapens, R. W. (1995). The changing nature of issues in management accounting. In D. Ashton, T. Hopper, \& R. Scapens (Ed.), Issues in management accounting ( $2^{\text {nd }}$ ed., pp. 1-20). Hertfordshire: Prentice Hall.

Baines, A., \& Langfield-Smith, K. (2003). Antecedents to management accounting change: A structural equation approach. Accounting, Organizations and Society, 28(7-8), 675-698.

Burns, J., \& Scapens, R. W. (2000). Conceptualizing management accounting change: An institutional framework. Management Accounting Research, 11(1), 3-25.

Burns, J., \& Vaivio, J. (2001). Management accounting change. Management Accounting Research, 12(4), 389-402.

Dupont, W. D., \& Plummer Jr, W. D. (1990). Power and sample size calculations: A review and computer program. Controlled Clinical Trials, 11(2), 116-128.

Hopwood, A. G. (2009). The economic crisis and accounting: Implications for the research community. Accounting, Organizations and Society, 34(6-7), 797-802.

Jacobs, K. (1995). Budgets: A medium of organizational transformation. Management Accounting Research, 6(1), 59-75.

Jones, T. A. (1998). UK hotel operators' use of budgetary procedures. International Journal of Contemporary Hospitality Management, 10(3), 96-100.

Khajavi, S., \& Nazemi, A. (2006). Innovation in management accounting: The needs of world-class firms. International Journal of Academic Research, 2(1), 320-330. 
Langfield-Smith, K. (1997). Management control systems and strategy: A critical review. Accounting, organizations and society, 22(2), 207-232.

Lev, B., \& Zambon, S. (2003). Intangibles and intellectual capital: An introduction to a special issue. European Accounting Review, 12(4), 597-603.

Libby, T., \& Waterhouse, J. H. (1996). Predicting change in management accounting systems. Journal of Management Accounting Research, 8, 137-150.

Lin, Z. J., \& Yu, Z. (2002). Responsibility cost control system in China: A case of management accounting application. Management Accounting Research, 13(4), 447-467.

Malmi, T., Seppala, T., \& Rantanen, M. (2001). The practice of management accounting in Finland: A change? The Finnish Journal of Business Economics, 50(4), 480-501.

Otley, D. T., \& Berry, A. J. (1980). Control, organisation and accounting. Accounting, Organizations and Society, 5(2), 231-244.

Pavlatos, O., \& Kostakis, H. (2015). Management accounting practices before and during economic crisis: Evidence from Greece. Advances in Accounting, 31(1), 150-164.

Sorensen, J. E. (2009). Management accountants in the United States: Practitioner and academic views of recent developments. In C. S. Chapman, A. G. Hopwood, \& M. D. Shields (Ed.), Handbook of management accounting research (Vol. 3, pp. 1271-1296). Oxford, UK: Elsevier.

Subasinghe, J., \& Fonseka, A. T. (2009). Factors affecting the low adoption of management accounting practices in Sri Lankan business organizations. Sri Lankan Journal of Management, 14(2), 95-114.

Sunarni, C. W. (2013). Management accounting practices and the role of management accountant: Evidence from manufacturing companies 
throughout Yogyakarta, Indonesia. Review of Integrative Business and Economics Research, 2(2), 616-626.

Szychta, A. (2002). The scope of application of management accounting methods in Polish enterprises. Management Accounting Research, 13(4), 401-418.

Tuan Mat, T. Z., Smith, M., \& Djajadikerta, H. (2010). Management accounting and organisational change: An exploratory study in Malaysian manufacturing firms. Journal of Applied Management Accounting Research, 8(2), 51-80.

Uyar, A. (2010). Cost and management accounting practices: A survey of manufacturing companies. Eurasian Journal of Business and Economics, 3(6), 113-125.

Van der Stede, W. A. (2011). Management accounting research in the wake of the crisis: Some reflections. European Accounting Review, 20(4), 605-623.

Verbeeten, F. H. (2010). The impact of business unit strategy, structure and technical innovativeness on change in management accounting and control systems at the business unit level: An empirical analysis. International Journal of Management, 27(1), 123-143.

Waweru, N. M., Hoque, Z., \& Uliana, E. (2005). A survey of management accounting practices in South Africa. International Journal of Accounting, Auditing and Performance Evaluation, 2(3), 226-263.

World Bank Group (2019). Retrieved from https://wits.worldbank.org/Count ryProfile/en/Country/BGD/Year/2010/TradeFlow/Export

World Bank Report (2019). Retrieved from https://data.worldbank.org/indic ator/ny.gdp.mktp.kd.zg?end=2007\&locations $=$ bd\&start $=2000$

Yazdifar, H., \& Tsamenyi, M. (2005). Management accounting change and the changing roles of management accountants: A comparative 
analysis between dependent and independent organizations. Journal of Accounting \& Organizational Change, 1(2), 180-198.

Zafar, J., Shaukat, M., \& Mat, N. (2010). An analysis of e-human resource management practices: A case study of state bank of Pakistan. European Journal of Social Sciences, 15(1), 18-26. 